NOTES ON NORTH AMERICAN NITIDULIDAE, III : PHENOLIA, SORONIA, LOBIOPA, AMPHOTIS

\author{
By C. T. PARSONS
}

Biological Laboratories, Harvard University

Erichson, who erected the genera Phenolia, Soronia, Lobiopa, and Amphotis, in 1843, had a clearer idea of their relationships than subsequent workers. For instance, Reitter placed Phenolia, and Lobiopa in Soronia; whereas Horn suppressed Amphotis as well as Lobiopa but resurrected Phenolia. Later Sharp and then Grouvelle, without giving reasons, raised them all to the good standing they have had subsequently. Since all of the writers have made mistakes in their diagnoses and since their descriptions have been incomplete, the genera are here redescribed.

1. Front lobed over the insertion of the antennæ 2.

Front not lobed over the insertion of the antennæ Phenolia Er.

2. Antennal grooves parallel 3. Antennal grooves strongly convergent posteriorly Soronia Er.

3. Mentum not emarginate anteriorly Lobiopa Er. Mentum emarginate anteriorly Amphotis Er.

\title{
Phenolia Erichson
}

Phenolia Erichson, 1843, in Germar, Zeitschr. Ent., 4: 299. Soronia (pars) Reitter, 1873, Syst. Eintheil, Nitid., p. 47.

The front not lobed over the insertion of the antennæ; eye facets about as in Lobiopa, coarser than in Soronia and Amphotis; mandibles bidentate at tip; antennal grooves parallel; labrum feebly bilobed; labial palpi incrassate; mentum distinctly pentagonal; prosternum behind the coxæ expanded and deflexed; elytra feebly costate; epi- 
pleuræ extending to apex of elytra but not to the suture; anterior tarsi feebly, middle more feebly, and posterior very feebly dilated.

Phenolia is Nearctic in distribution and contains only one variable species.

\section{Phenolia grossa (Fabricius)}

Nitidula grossa Fabricius, 1801, Syst. Eleuth., 1: 347.

This species is found beneath bark and in fungi from Canada and Maine to Wyoming and Texas.

\section{Soronia Erichson}

Soronia Erichson, 1843, in Germar, Zeitschr. Ent., 4: 277.

The front lobed over the insertion of the antennæ; eye facets about as in Amphotis, finer than in Lobiopa; mandibles bifid at tip, the inner cusp slightly proximal to the outer and smaller; antennal grooves strongly convergent posteriorly; labrum feebly bilobed or emarginate, labial palpi filiform, mentum rectangular with small process in center of anterior margin; elytra very feebly costate; epipleurae may extent to the suture; tarsi very feebly dilated; outline more oblong and less oval than in Lobiopa.

Although Soronia is widely distributed in the Old World, only three species are known from the New World, one each from North America, Brazil, and Mexico to Brazil. Blatchley and Hamilton each described a species from eastern United States. Both species, however, belong in Lobiopa.

\section{Soronia guttulata (Leconte)}

Lobiopa guttulata Leconte, 1863, Smiths. Misc. Coll., 6: 64. Leconte described this species from a specimen collected by Ulke in Illinois. In the Leconte collection there is no specimen from Illinois, but there is one from Canada labelled "type" and one each from Marquette, Michigan and Arizona. It has been taken in New York, and specimens from Iowa, Oregon, and California (McCloud, Carrville, and Facht) have been seen. The dates of capture are from April to June 26. 


\section{Lobiopa Erichson}

Lobiopa Erichson, 1843, in Germar, Zeitschr. Ent., 4: 291. Cerophorus (pars) Castelnau, 1840, Hist. Nat. Col., 2 : 10. Soronia (pars) Reitter, 1873, Syst. Eintheil. Nitid., p. 46. Horn, 1879, Trans. Am. Ent. Soc., $7: 306$.

Front lobed over the insertion of the antennæ; mandibles bifid at tip, the inner cusp may be smaller than the outer; eye facets about as in Phenolia, coarser than in Soronia; labrum feebly bilobed; labial palpi more or less incrassate; antennal grooves parallel; mentum rectangular with a small process at center of anterior margin; elytra not costate; epipleurae not extending around apex of elytra; tarsi very feebly dilated.

Lobiopa contains a number of species confined to the New World. In addition to the three species already in the North American list, one is transferred from Soronia, three are described as new, and one described as a Soronia is synonymized.

1. Six or seven distinct rows of setae on the disc of each elytron

About nine distinct rows of setæ on the disc of each elytron setosa Harold.

2. From above, eyes not as long as pronotal emargination is deep

From above, eyes as long or longer than pronotal emargination is deep

3. Distinctly less than twice as long as wide

4. Twice as long as wide oblonga n. sp.

4. Submentum finely punctate, length $3.6-5.3 \mathrm{~mm}$. undulata (Say).

Submentum coarsely punctate, length 5.3-6.7 mm. falli n. sp.

5. Above with pubescence, setæ, and coarsely punctate, length more than $4.4 \mathrm{~mm}$.

Above nearly glabrous, finely punctate, length 3.5-4.5 $\mathrm{mm}$.

brunnescens Blatch.

6. Lateral margins narrowly explanate .......punctata n. sp. Lateral margins broadly explanate ..... insularis (Cast.). 


\section{Lobiopa setosa Harold}

Fig. 5.

Lobiopa setulosa Leconte (non Erichson), 1863, Smiths. Misc. Coll., 4: 63.

Lobiopa setosa Harold, 1868, Col. Hefte, 4: 104.

Soronia undulata (pars) Horn, 1879, Trans. Am. Ent. Soc., $7: 307$.

Soronia substriata Hamilton, 1893, Can. Ent., 25 : 306.

Dr. Hugo Kahl kindly sent me the type of substriata Hamilton. After comparison with the type in the Leconte collection, substriata turns out to be a synonym of setosa. The type of substriata is one millimeter longer than Leconte's type, darker above, with slightly more pointed elytra. Since individuals in this genus are very variable, these differences are unimportant. This rare species tends to be broader, more depressed, duller, and darker than its closest relative undulata. Specimens have been seen ranging from Massachusetts to Utah, north to Kamloops, B. C., March 21. In Pennsylvania it has been found in May under the bark of maple (Acer rubrum).

Lobiopa oblonga new species

Fig. 6.

Length twice the width, oblong oval, feebly convex. Above dull rufo-piceous with faint, irregular, pale maculæ. Margins of thorax and elytra rufo-testaceous. Beneath, including antennæ and legs, dark rufo-testaceous. Head pubescent; closely, finely punctate; very broadly, shallowly impressed between the eyes. The lobes over the insertion of the antennæ more prominent than in all the other North American species except falli $\mathrm{n}$. sp. Labial palpi incrassate. Prothorax more emarginate anteriorly than brunnescens but less so than the other North American species; with broadly explanate, flatly arcuate lateral margins; hind angles rather broadly rounded; hind margin feebly bisinuate; surface closely finely punctate, finely pubescent, sparsely covered with short pale setæ. Prosternal process relatively more narrow between the coxæ than in the other 
species. Visible part of scutellum forming an equilateral triangle. Elytra with broadly explanate, feebly arcuate margins; closely, finely punctate; finely pubescent; each elytron with six or seven rows of pale setæ. Beneath closely finely punctate, rather sparsely pubescent. Length of holotype $5.0 \mathrm{~mm}$., width $2.5 \mathrm{~mm}$. ; allotype $4.2 \mathrm{~mm}$., width $2.2 \mathrm{~mm}$.

Described from the female holotype, Marble Fork Bridge, 3000-5000 ft., Sequoia National Park, California, June 12, 1929; and male allotype, Upper Soda Spring, Siskiyou
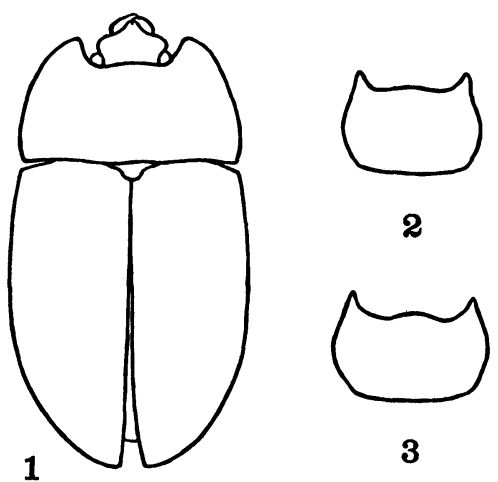

3
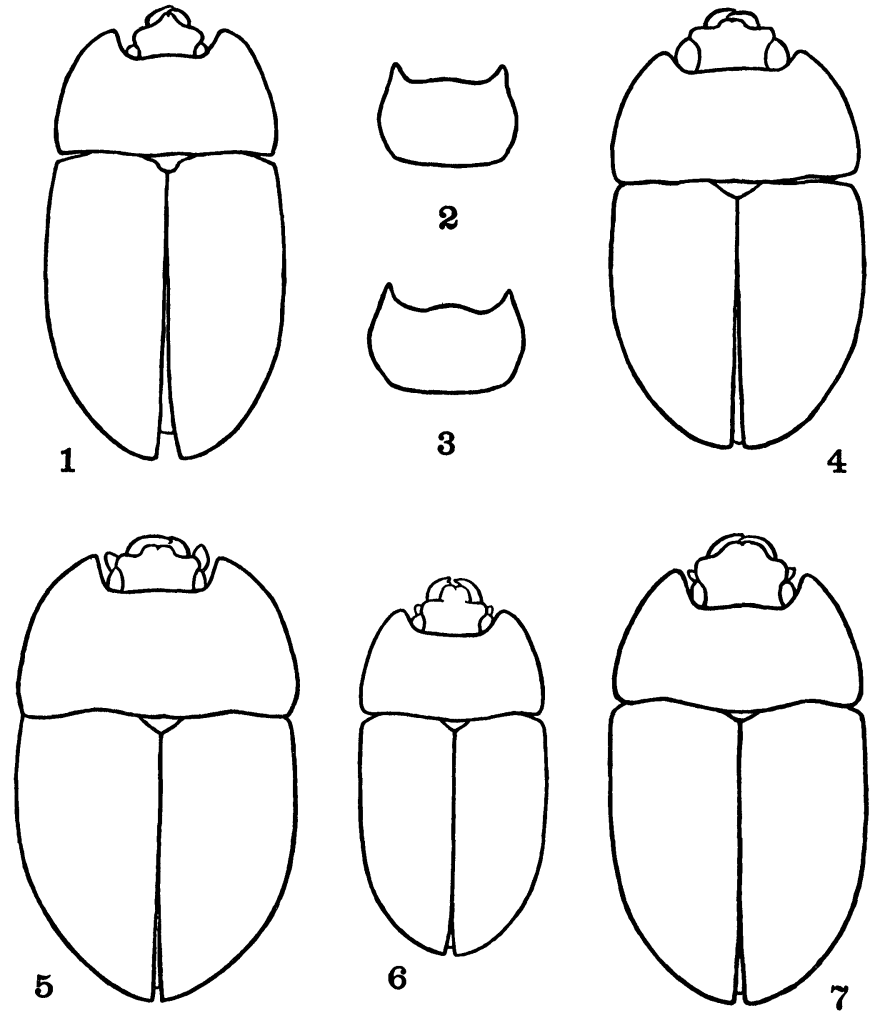

Figs. 1-7. 1, Amphotis schwarzi (cotype) ; 2, mentum of same; 3, mentum of A. ulkei (topotype) ; 4, Lobiopa punctata n. sp. (holotype); 5, L. setosa (holotype of substriata) ; 6, L. oblonga n. sp. (holotype) ; 7, L. falli n. sp. (holotype). 
County, California, Aug. 6, 1906, E. N Erhrkom collector; both in the Van Dyke collection of the California Academy of Sciences.

This species, apparently closest to falli n. sp., is distinctive in its oblong form. It is less convex than brunnescens, punctata n. sp., and falli n. sp. but more convex than the other species.

\section{Lobiopa undulata (Say)}

Nitidula undulata Say, 1825, Journ. Acad. N. S. Philad., $5: 179$.

Soronia undulata Horn, 1879, Trans. Am. Ent. Soc., $7: 307$. Lobiopa undulata Sharp, 1890, Biol. Centr.-Amer. Col., vol. 2 , pt. 1, p. 321.

This species varies considerably in color, shape, and size (3.6-5.3 mm.). It is found at sap in the spring and autumn and hibernates beneath logs. The range is Maine and Michigan to Florida, Texas, and "northern Sonora" (Sharp). Sharp's record may refer to the following new species.

\section{Lobiopa falli new species}

Fig. 7.

More oval than oblong; feebly convex. Above dull rufopiceous with the margins of the prothorax and elytra rufotestaceous. Also there is on the upper surface faint, irregular, pale maculæ, in particular usually a transverse pale band at the posterior third extending half way across each elytron. This band is more evident in insularis and undulata. Beneath rufo-piceous with the legs paler. Head with a few, thick, erect setæ; pubescent; rather coarsely compactly punctate; alutaceous; with a broad, transverse impression between the eyes; lobes over the insertion of the antennæ very prominent, more so than in the other North American species. Eyes of ordinary size. Labial palpi incrassate. Prothorax as emarginate anteriorly as in setosa and undulata, more so than in insularis, in which the prothorax is more emarginate than in oblonga $\mathrm{n}$. sp. Prothorax with lateral margins broadly explanate, evenly and flatly arcuate, narrowing shortly before the acute hind angles; 
hind margin distinctly bisinuate; surface closely and rather coarsely punctate, alutaceous, pubescent, sparsely covered with thick setæ. Visible part of the scutellum forming a strongly transverse triangle. Elytra with broadly explanate margins; rather close, coarse, obsolete punctures; alutaceous; finely pubescent; each elytron with about seven rows of thick setæ. Beneath coarsely punctate, sparsely and finely pubescent. Length 5.3-6.7 mm., width 3.1-4.1 mm.

Holotype female, allotype male, and 2 paratypes from Arizona in the Leconte collection, Museum Comp. Zool.; 14 paratypes from 6-7000 ft., Stratton, S. Catalina Mts., July 27, 1917, W. M. Wheeler collector; 1 paratype, Patagonia Mts., Arizona, July 20-Aug. 6, 1930 in the Mus. Comp. Zool. In the U.S.N.M. 25 paratypes from Oracle, Arizona, October 7; 4 paratypes from Palmerlee, Arizona; 7 paratypes from the Santa Rita Mts. and Fort Grant, Arizona. In the University of Kansas collection 4 paratypes from the Chiricahua and Huachuca Mts., July-Aug. One paratype each from Prescott, Arizona, Chisos Mts. and Alpine, Texas, July, in the collection of H. C. Fall. Also 2 paratypes from the Huachuca Mts., 2 paratypes from Oracle, June 7, and 3 paratypes from Globe, Arizona in the collection of the author.

This species varies in outline and in color. In the pale specimens the maculation is most evident, whereas in those that are piceous the maculation is not discernible. The species is distinctive in the prominent lobes over the insertion of the antennae, transverse scutellum, and the unusual covering of thick setæ. It is apparently related to undulata; in fact Mr. Fall has specimens of undulata from Texas which approach falli in the maculation, setæ and lobes over the insertion of the antennæ. But in falli the scutellum is more transverse, punctures beneath more coarse, and shape usually more oval.

\section{Lobiopa brunnescens (Blatchley)}

Soronia brunnescens Blatchley, 1917, Can. Ent., 49: 238.

This species is definitely a Lobiopa and related to insularis. The types are from Dunedin, Florida, June 10. In addition there are specimens in the U.S.N.M. from Coving- 
ton, La., June 13 which differ from the types in showing faint maculation similar to that in insularis and slightly coarser punctation of the prothorax. It is remarkable that F. M. Jones collected a specimen Aug. 21, 1931 on Martha's Vineyard, Mass. This specimen, which is in the Boston Soc. Nat. Hist., has no maculation as in the types. Apparently this record cannot be accounted for by hurricanes, since the last one passed over Martha's Vineyard in 1928.

\section{Lobiopa punctata new species}

Fig. 4.

Oblong oval, rather strongly convex, shining, rufo-testaceous above and beneath. Head sparsely pubescent, closely, coarsely punctate; broadly impressed between the eyes; lobes over the insertion of the antennæ more transversely produced than in the other North American species; labial palpi incrassate. Prothorax as emarginate in front as brunnescens, therefore less emarginate than in the other North American species; lateral margins narrowly explanate and evenly arcuate; hind angles broadly rounded and obtusely angled; hind margin feebly bisinuate; surface closely, coarsely punctate, with sparse pubescence and with sparser small setæ. Prosternal process only slightly reflexed behind the coxæ. Elytra with narrowly explanate, feebly arcuate lateral margins; eight rows of small setæ; finely pubescent; each elytron with two pale spots extending across anterior median agle, a transverse pale band across inner half at posterior third, and center somewhat darker. Beneath closely, coarsely punctate, finely pubescent. Length 5.2-4.5 mm., width 3.1-2.5 mm.

Described from four males; holotype and paratype from Miami, Florida, March 11, 1924 in the collection of H. C. Fall; one paratype from Miami, Florida, March 31 in the Van Dyke collection in the Calif. Acad. of Sciences; and a paratype from Balaclava, Jamaica, A. E. Wright, in the Mus. Comp. Zoology.

This species is apparently closest to brunnescens, particularly in the convexity of the body and degree of emargination of the pronotum. It differs from brunnescens in its larger size, much coarser punctation and pubescence, nar- 
rower lateral margins, and in the prosternal process being only slightly arched longitudinally between the coxæ; whereas in brunnescens the prosternal process is strongly arched between the coxæ and reflexed posteriorly.

\section{Amphotis Erichson}

Amphotis, Erichson, 1843, in Germar, Zeitschr. Ent., 4: 290. Soronia (pars) Horn, 1879, Trans. Amer. Ent. Soc., 7 : 287.

Front lobed over the insertion of the antennæ; labrum feebly bilobed; mandibles bifid at tip; labial palpi filiform; eye facets about as in Soronia, finer than in Lobiopa; antennal grooves parallel; mentum emarginate; elytra distinctly costate; epipleurae extend to suture; tarsi feebly dilated.

Amphotis contains two North American and three European species.

\section{Amphotis ulkei Leconte}

Fig. 3.

Amphotis ulkei Leconte, 1866, Proc. Ac. N. S. Philad., p. 376. Soronia ulkei Horn, 1879, Trans. Amer. Ent. Soc., 7 : 307.

This species extends from Massachusetts to the District of Columbia in the nests of Crematogaster lineolata, Formica schaufussi, and Formica integra. It is strictly myrmecophilous in the early spring but in the fall of the year is found in decaying fungi.

\section{Amphotis schwarzi Ulke}

Fig. 1, 2.

Amphotis schwarzi Ulke, 1887, Ent. Amer., 3: 77.

Dr. Hugo Kahl of the Carnegie Museum has kindly loaned me the types (collected by Schwarz June 17 at Ft. Monroe, Virginia), all of which are testaceous. Two specimens in the U.S.N.M. from Mobile, Alabama, December 6 are dark testaceous, and a specimen from Southern Pines, N. C., March 3 in the collection of C. A. Frost is rufo-piceous. This species differs from ulkei in the additional two costæ on each elytron and in the narrower and less emarginate mentum. 

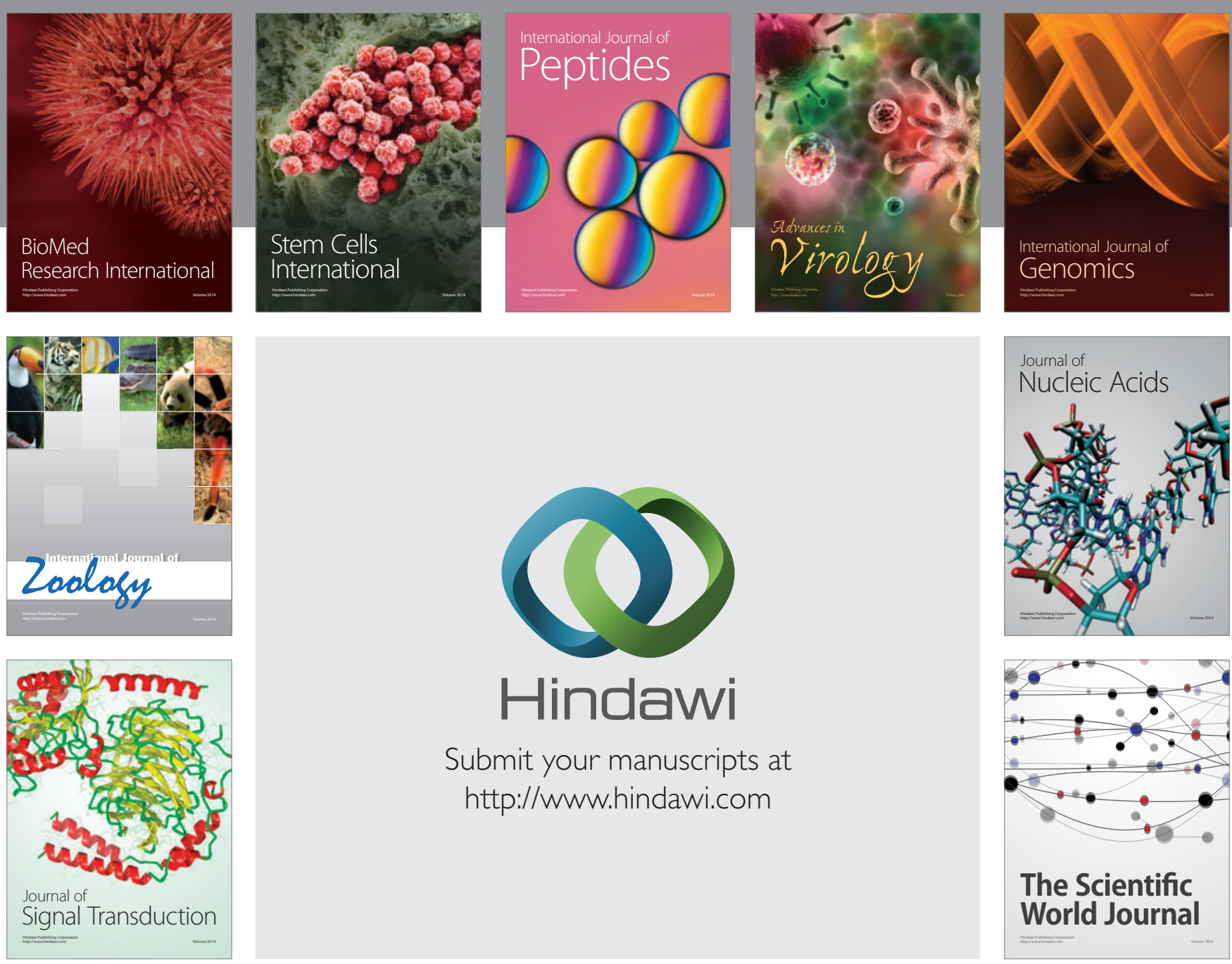

Submit your manuscripts at

http://www.hindawi.com
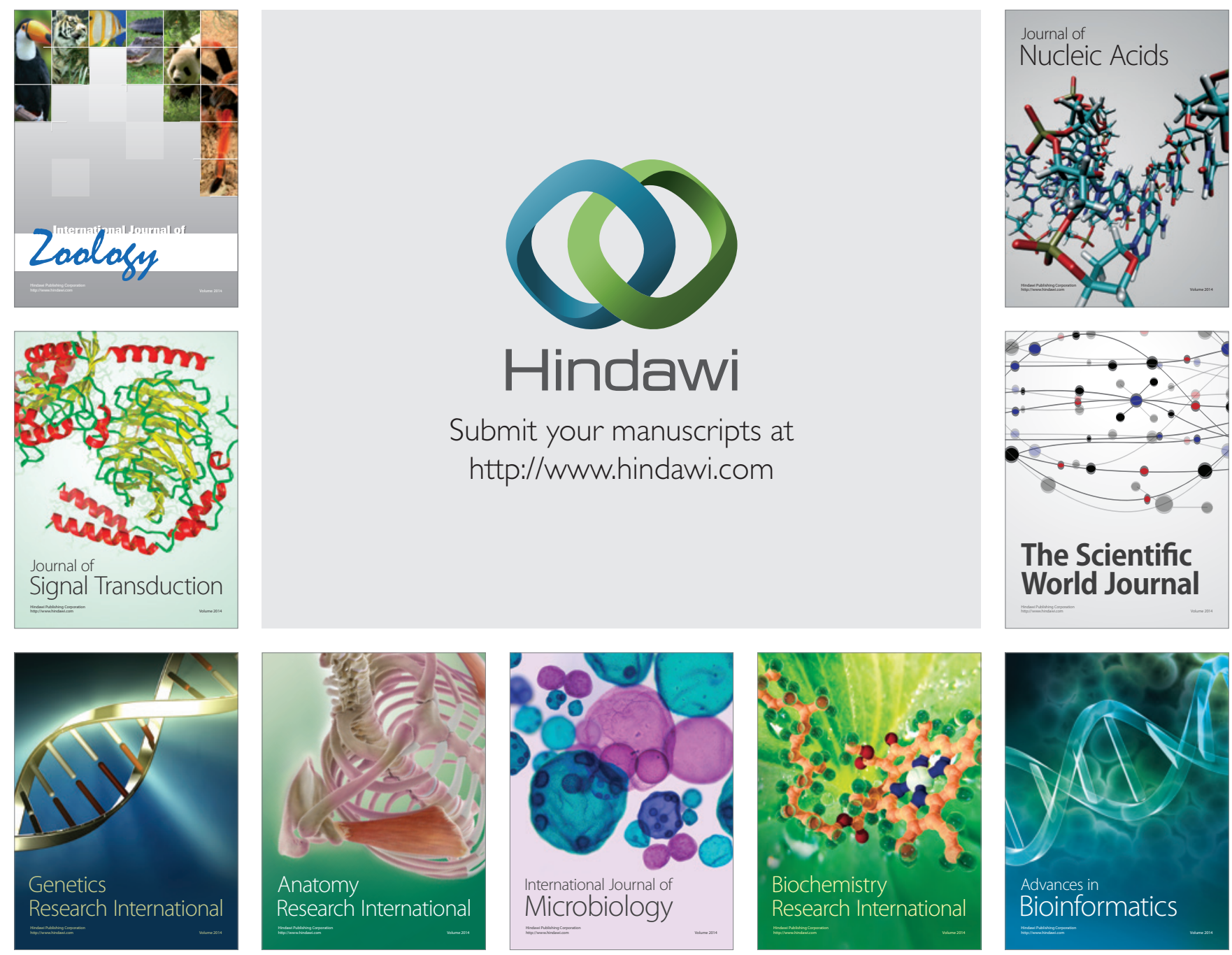

The Scientific World Journal
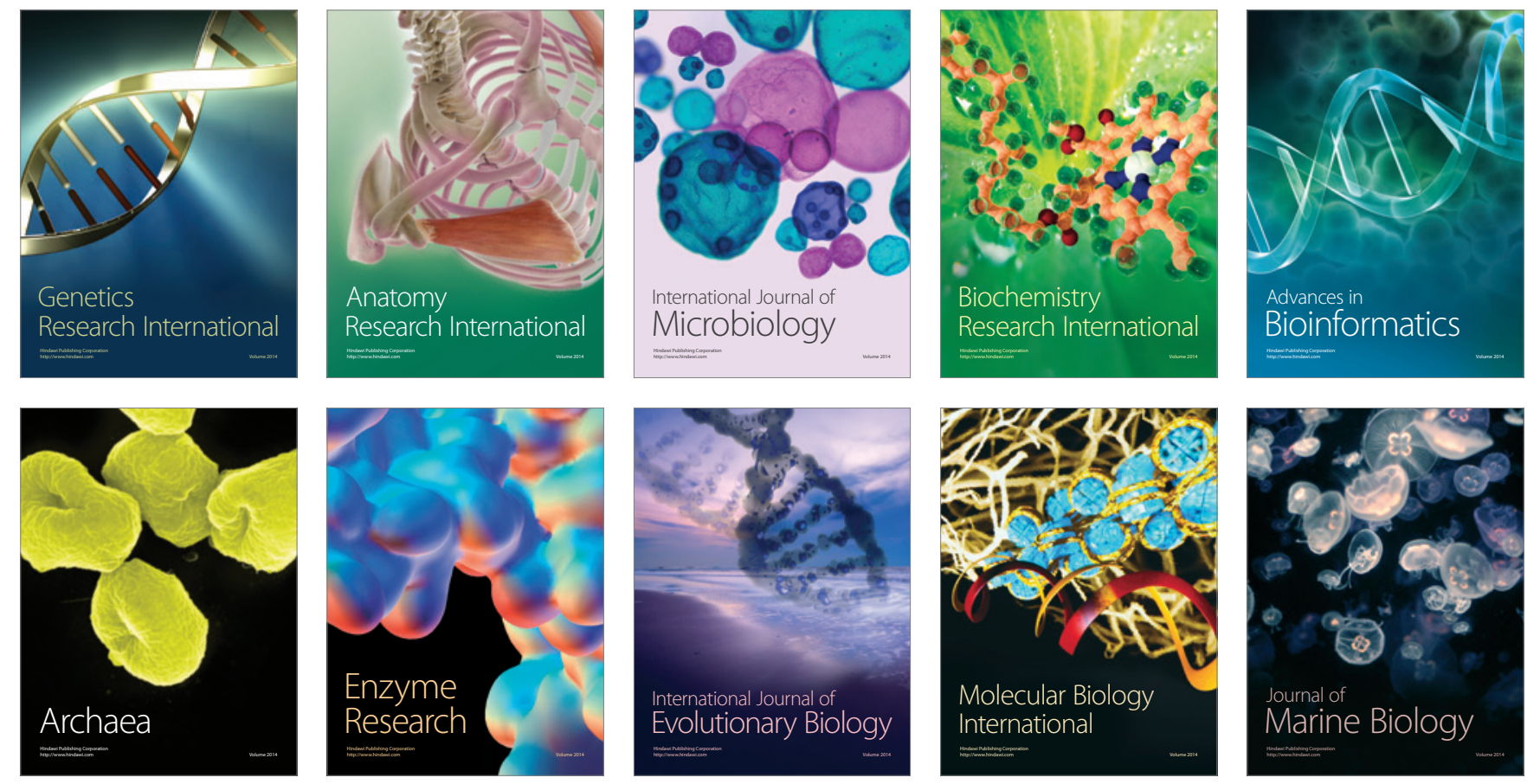